AWEJ for Translation \& Literary Studies, Volume 5, Number 2. May 2021

DOI: http://dx.doi.org/10.24093/awejtls/vol5no2.7

Pp. 91-103

\title{
Love in Charles Dickens's Great Expectations: A Psychoanalytic Approach
}

\section{Bechir Saoudi}

English Department, College of Science and Humanities, Hotat Bani Tamim, Prince Sattam Bin AbdulAziz University, Al-Kharj, Riyadh, Kingdom of Saudi Arabia English Department, ISEAH, Kef, Jendouba University, Tunisia Correspondent Author: ctat.ctat@yahoo.com

\section{Ameerah Ali Al-Bedewy}

English Department, College of Science and Humanities, Hotat Bani Tamim, Prince Sattam Bin AbdulAziz University, Al-Kharj, Riyadh, Kingdom of Saudi Arabia

Fatima Ali Al-Anzan

English Department, College of Science and Humanities, Hotat Bani Tamim, Prince Sattam Bin AbdulAziz University, Al-Kharj, Riyadh, Kingdom of Saudi Arabia

Lulwah Mohammad Al-Sebr

English Department, College of Science and Humanities, Hotat Bani Tamim, Prince Sattam Bin AbdulAziz University, Al-Kharj, Riyadh, Kingdom of Saudi Arabia

\section{Nouf Mohammad Al-Smari}

English Department, College of Science and Humanities, Hotat Bani Tamim, Prince Sattam Bin AbdulAziz University, Al-Kharj, Riyadh, Kingdom of Saudi Arabia

\section{Nora Ali Al-Tamimi}

English Department, College of Science and Humanities, Hotat Bani Tamim, Prince Sattam Bin AbdulAziz University, Al-Kharj, Riyadh, Kingdom of Saudi Arabia

\begin{abstract}
This research project studies love in Charles Dickens's Great Expectations through Pip's ego fluctuations. Freud's division of the human psyche into the three components of id, ego and superego is applicable to the analysis of the rise and fall of the hero in his quest for Estella's love. Four main questions have been dealt with: First, what makes up Pip's id when it comes to love? Second, what are the main components of his superego that stand in the way of his love? Third, does Pip's ego succeed in striking a balance between his id and superego? In what ways does it fail? And fourth, how does it eventually succeed if ever? The study has managed to answer its key research questions: First, Pip's id is illustrated in the feelings and actions exerts in order to win Estella's love. Second, Pip's superego is mainly made up of the attitudes of characters that stand in his way. Third, Pip's distress at the attitudes of Estella, Miss Havisham, Biddy and his friends, bring Pip's ego to its worst situation. Fourth, the quest of Pip's ego for winning Estella's heart finally becomes possible mainly thanks to Miss Havisham's repentance and Estella's transformation. Keywords: Charles Dickens, ego, Freud, Great Expectations, id, love, superego

Cite as: Saoudi, B., Al-Bedewy, A.A., Al-Anzan, F. A., Al-Sebr, L. M., Al-Smari, N.M. \& Al-Tamimi, N.A. (2021). Love in Charles Dickens's Great Expectations: A Psychoanalytic Approach. Arab World English Journal for Translation \& Literary Studies 5 (2) 91-103. DOI: http://dx.doi.org/10.24093/awejtls/vol5no2.7
\end{abstract}




\section{Introduction}

Charles Dickens was one of the most prominent British Victorian writers. He wrote the valuable classics of A Christmas Carol, A Tale of Two Cities, David Copperfield, Hard Times, Nicholas Nickleby, Oliver Twist, and Great Expectations. He also greatly influenced such major writers as Conrad, Eliot, Joyce and Kipling.

Great Expectations is one of Dickens's "greatest critical and popular successes" ("Great," 2020, para. 1). It is Dickens's greatest accomplishment, first published in book form in 1861. It relates the emotional development of its hero. Pip's love for Estella is "one of the main themes of Dickens' Great Expectations and Pip's main motivation for becoming a gentleman" (Hrubes, 2003, p.4). The novel also addresses "such issues as ambition, self-improvement, social class, crime, guilt, innocence, sophistication and human worth" (Saoudi, et al., 263).

Great Expectations has been widely held among both readers and literary critics (Schlicke, 1999). It has been analyzed from various critical lenses including psychoanalysis. However, Freud's three psychoanalytic division of the human mind into id, ego and superego, has not been satisfactorily explored in relation to the central character, exception made of Saoudi et al., (2021). In their article, Saoudi et al. investigate Pip's journey towards attaining gentlemanhood using Freud's notions.

\section{Thesis Statement}

This research project aims at studying Pip's psyche using Freud's notions of id, ego and superego in relation to the hero's journey to earn Estella's love.

\section{Key Research Questions}

The study seeks to answer important questions posed in Psychoanalytic literary criticism through the examination of Pip's personality in Great Expectations. What represents Pip's id as far as love is concerned? What makes up his superego in terms of the hurdles that stand in the way? How does Pip's ego succeed or fail in striking a balance between his id and superego?

\section{Significance and Purpose of the Study}

This literary study is very rewarding in that it fills a gap in knowledge that has not fully been addressed in relation to the theme of love, namely the application of Freudian criticism to Great Expectations in the quest for comprehending the complex relationships between the hero's id, ego and superego. It aspires to examine the work in order to discover the fluctuations of the ego between the id and the superego and evaluate their effects. This kind of study has been highly recommended by Saoudi, et al., (2021). It also provides the opportunity for students to experiment with literary criticism principles and apply them to actual texts. The project will expectantly embolden more students to opt for literary projects.

\section{Literature Review}

Great Expectations has impelled various kinds of evaluations from different critics using an array of critical approaches. In this study, the researchers are keen on applying "the psychoanalytical theory whose progress has had an enormous impact on literary criticism" (Saoudi, et al., 2021, p. 
264). The authors (Saoudi, et al., 2021) maintain that psychoanalytic criticism could be approached in many ways including laying the focus on the way Dickens's own life impacted his work, on the readers' psychological identification with the characters in the novel, on the relationships between a character and society, and/or on the psychoanalytic analysis of one or more characters. The current study focuses on the last approach.

A number of studies, mentioned in Saoudi, et al. (2021), have analyzed Great Expectations from psychoanalytic perspectives. One of the reasons is that the novel "enters the abyss of Pip's inner self" (Bloom, 2010, p. 1). In "Great Expectations: 'The Ghost of a Man's Own Father'" (1976), Dessner examines the multifaceted relationship between Dickens, the dreamer and Pip, his dream. Brooks (1980) explores Great Expectations using the concept of repetition in Freud's Beyond the Pleasure Principle.

In "Repressions in Great Expectations" (2004), Lehman scrutinizes the novel for the ways "repressed feelings, thoughts, and actions [...] offer greater depth of meaning to the plot and its characters" (para. 1). In "The Superego, Narcissism and Great Expectations" (2008) Ingham sheds light on the ways narcissism may be perceived as a product of the superego. Tyler (2011) probes the "delineation of Pip's future-oriented psychology" and defines "Pip's feelings of uncertainty about the future" (p. 1). Reynolds (2015) examines Pip and Estella's love relationship and the way they "have resolved some of their maladaptive psychology" (2015, para 8).

Freud's basic psychoanalytic notions of the id, ego and superego have not been fully investigated in relation to the theme of love in Great Expectations. Hence, it is crucial to address the gap and probe Pip's psyche using basic Freudian jargon.

\section{Theoretical Framework}

This study deals with the application of three major parts of the psyche in Freudian psychoanalytic literary criticism to the theme of love in Great Expectations. In The Ego and the Id (1927), Freud perceives the human mind as composed of three elements, the id, the ego, and the superego.

Saoudi et al. maintain that the "id is the center of a person's instincts" (2021, p. 265). Snyder and Lopez (2007) depict it as mainly sexual in nature and driven by pleasure. The superego embodies the shared moral values and social rules people are bound to abide by; it is determined by reality (Freud, Strachey, \& Richards, 1984). The superego stands at the opposite end of pleasure that manipulates the id.

Saoudi et al., (2021) state that the ego plays the role of mediator between the id and the superego. If the ego succeeds in restraining the id-superego conflict in the mind, it turns into a healthy functional ego, as opposed to a faulty defective ego if it misses the mark and fails in the mission. In the present study, the Freudian concepts of id, superego, faulty and healthy ego shall be respectively dealt with in the four main parts of the project following the research design.

\section{Research Design}

The study of Pip's ego fluctuations between the id and superego in his quest for love in Great Expectations uses close textual analysis with the guiding principles of Freud's concepts. It is divided into four main parts. Part one demonstrates the ways Pip's id is revealed through his desire 
to gain Estella's love by means of both emotional expression and actual deeds. Part two studies Pip's superego as displayed mainly through the characters that stand in the way of his love: namely Miss Havisham and Estella.

Part three deals with the failings of Pip's ego in striking a balance between his id and superego, leading towards a faulty ego. The failings are caused by Miss Havisham's deceit and revenge plot, Estella's incapability of love and other factors related to Biddy and Pip's other friends.

Part four concerns the successes of the ego in learning from failures in order to eventually reach a level of satisfaction in love. Estella's own suffering, Miss Havisham's repentance, the hero's transformation and other factors related to Biddy highly contribute to the healing of Pip's ego.

\section{Part One: The Id}

Pip's great expectations are representative of his id as he seeks gratification of three vital needs throughout the novel: security, gentlemanhood and love (Saoudi et al., 2021). This project is devoted to the study of love, a basic component of the id that is at the heart of the pleasure principle. Pip's id is articulated through displays of his unrelenting resolve to earn Estella's love. It is expressed mainly through Pip's feelings and actions.

\section{Pip's Feelings}

Pip falls in love with Estella from first sight and continues to love her until the end of the novel, admitting that every day she grows more and more a part of his thoughts (Dickens, 1861, Chap. 12). Estella, meaning star, is a "very pretty" and "very proud" girl (Chap. 8, p. 96). She also studied abroad and developed sophisticated manners (Chap. 29). Besides, the older she gets, the more beautiful she becomes, and the more fascinated and charmed Pip becomes (Chap. 29). He spends his time fantasizing about her (Chap. 19). He grows even fonder of her after she returns from France a gorgeous woman (Chap. 29). He convinces himself that Miss Havisham has adopted both him and Estella to raise them to be married to each other. He mistakenly understands the great expectations supposedly offered him by Miss Havisham as meaning that after Estella has retaliated against the male gender, her hand would be given him in marriage by the old lady as a reward (Chap. 38). This is driven by the fact that Miss Havisham talks excitedly to Pip about Estella, inciting him to "love her, love her" even if she perseveres in breaking his heart (Chap. 29, p. 425). She states that real love ought to be like hers, "blind devotion, unquestioning self-humiliation, utter submission, trust and belief against yourself and against the whole world, giving up your whole heart and soul to the smiter - as I did!" (Chap. 29, pp. 425-426). Soon Pip's motivations become wholly determined by Miss Havisham's stimulation and Estella's outlook, his only concern being to have the latter look up to him (Chap. 14)

In Chapter 33, Pip expresses his confidence that if he lives with Estella forever that would mean ultimate happiness for him. He already imagines himself and Estella residing at the Manor House with its windows flung open widely all around welcoming the sunshine and breeze in (Chap. 29). In Richmond, he visualizes how blissful he would be if he lived with Estella (Chap. 32). Pip has a great affection for Estella but is not aware of the extent of his love. He does not comprehend how evident his fascination with her is to others. When he tells Herbert about his love for Estella, he is shocked to hear that Herbert was already aware of it (Chap. 30). His love for her proves to be genuine as he prioritizes her happiness over his own. (Chap. 44). Even after she had been married

Arab World English Journal for Translation \& Literary Studies 
to, ill-treated, and divorced by her now deceased husband, Pip still desires to return to the Satis House to ruminate about her (Chap. 59).

In fact, Pip loves Estella in spite of all cautions and warnings. He himself declares that he "loved her against reason, against promise, against peace, against hope, against happiness, against all discouragement that could be" (Chap. 29, p. 411). Even when Estella warns him that she has no heart, "I have no softness there, no - sympathy - sentiment - nonsense," Pip refuses to believe her (Chap. 29, p. 421). She wants him to "take warning" of her feelings but he insists she does not mean it (Chap. 38, p. 475). And Even when he discovers her relation to convict Magwitch, his love and respect for the young lady never wavers (Chap. 30). Other people might show neutrality towards Estella, but not Pip. He is troubled by the contrast between Mr. Jaggers' "cold presence" and his own earnest feelings for Estella (Chap. 29, p. 431). Mr. Jaggers disregards her and pays no attention to her beauty. Yet, for Pip, Estella is "part of [his] existence, part of [him]self" (Chap. 44, p. 646).

\section{Pip's Actions}

Besides being expressed through his feelings, Pip's deep unrequited love for Estella is also articulated through his actions. He perseveres, makes sacrifices, and blindly complies with Estella's values. For Estella's sake, and for almost eight months, Pip accepts to push Miss Havisham in a wheelchair from her room to the hall and back (Chap. 12). He also kneels in front of Miss Havisham and kisses her hand (Chap. 19). When he is far distanced from Estella, he exploits every opportunity to journey back to meet her (Chap. 28 and 43). Impatient and restless to see Estella, he arrives at the coach station five hours ahead of her arrival. (Chap. 32) When, in Chap. 44, he eventually breaks down and confesses his love for Estella and she rejects him, he never gives up until the end. Towards the end of the novel, and even though he knows Estella got married to Drummle, he revisits the Satis House to recall his memories with the girl who jilted him (Chap. 59).

Pip also declares that he is bent on becoming a gentleman for Estella's sake, dreaming of being acceptable and loved by her (Chap. 17). That is why he refrains from identifying with Joe's "uncommon" ethics, focused as he has become on Estella's attitudes and standards by which he will abide for a long time (Chap. 9). His goals and values change with his infatuation with Estella. He soon grows dissatisfied with the life that "was all coarse and common" even though it had made him happy before meeting Estella (Chap. 14, p. 188). He starts studying autonomously and strains to share his education with Joe in the hope of instructing him out of commonness so that he "might be worthier of my society and less vulnerable to Estella's reproach" (Chap. 15, p. 193). Pip openly declares to Biddy his displeasure with his work at the forge and his ambition to be a gentleman so that Estella stops deriding his commonness (Chap. 17). When he returns to the village in Chapter 28, he avoids the forge and stays at the Blue Boar to satisfy Estella. He does not waver about not visiting Joe, knowing he would fall out of favor with his beloved (Chap. 29). He "necessarily" and not only "naturally" cuts off all connections with his past "companions" for the only sake of Estella (Chap. 29, p. 419). 
Pip's id, mainly his strong desire for Estella's love, is illustrated in both his strong feelings for her and the actions he undertakes to fulfill his dream. This ushers in the forces that would stand in his way and make up his superego.

\section{Part Two: The Superego}

In Freudian theory, "the human mind is structured around an id-superego relationship that represents the struggle between the pleasure principle and the reality principle" (Saoudi, et al, 2021, p. 267). While pleasure drives the id, reality guides the superego. In Pip's case, the superego is mainly constructed from hurdles that stand in the way of Pip's love for Estella, including Estella herself and Miss Havisham.

\section{Miss Havisham}

Miss Havisham, Estella's adoptive mother, is the main resident of the Satis House. "Satis," explains Estella, ironically means that the house is "Enough" to satisfy the desires of its members, which is far from being the case (Chap. 8, p. 98). On the contrary, the decomposing wedding table at the hall distorts the images of love and marriage and replaces them with an ugly scene of decay and fear (Chap. 11). Miss Havisham was abandoned by her fiancé on her wedding day. She brought up Estella to wreak revenge on the male race by seducing men into falling in love with her and then breaking their hearts "and have no mercy" (Chap. 12, p. 167). Pip simply happens to be one of her victims. "Well," says Miss Havisham, "you [Estella] can break his heart" (Chap. 8, p. 104). In Chapter 12, she draws Pip's attention to Estella's beauty, whispering warmheartedly to Estella to "Break their [men's] hearts, my pride and hope!" (p. 167). Furthermore, Herbert confirms the story, condemning Estella for being harsh and arrogant, and explaining to Pip that she is Miss Havisham's adopted daughter brought up to "wreak revenge on all the male sex" (Chap. 22, 311). In fact, Miss Havisham treats Pip as a toy as she initially needed him to come to her house in order to "play" (Chap. 8, p. 102). In Chapter 15, she laughs at him when he forgets about his initial reason to be at the Satis House and looks around for Estella.

\section{Estella}

Right from the outset, Estella expresses her denigration of Pip as just a "common laboring boy" (Chap. 8, p. 104). Even while he is growing more and more gentleman-like and Estella more and more attractive, she continues to treat him like a boy. When he meets her after years, he psychologically "[slips] hopelessly back into the coarse and common boy again" (Chap. 29, p. 416). For Estella reacts only to his physical appearance and social rank, not to his loving character (Chap. 8). She associates love feelings with nonsense. "I have a heart to be stabbed in or shot in," she tells Pip, "[...] I have no softness there, no - sympathy - sentiment - nonsense" (Chap. 29, p. 421). "O the sense of distance and disparity that came upon me, and the inaccessibility that came about her!" he exclaims (Chap. 29, p. 416). The last straw that broke his back was when she started courting Drummle, the most abhorrent man to Pip, and finally got married to him. An additional factor that distracts Pip from Estella's love is Biddy. Pip accuses her of begrudging him partly because of his love for Estella. He accuses her of having "a bad side of human nature" (Chap. 35, p. 503). 
Pip's superego is constructed from the characters that stand in the way of his pursuit of love: Estella and Miss Havisham. Their contribution to Pip's faulty ego is studied in more detail in the next section. Will Pip's ego be able to negotiate a deal between his id and superego? The answer is two-fold: He first fails before he can learn from his faults and end up embracing some success in earning Estella's love. The next section deals with Pip's ego's failures.

\section{Part Three: Faulty Ego}

Pip's ego tries its best to negotiate a deal between his id and superego. The outcome oscillates between success and failure. This part deals with Pip's love disappointments emanating from Miss Havisham, Estella, Biddy, his other friends, and Pip himself.

\section{Miss Havisham: Deceit and Revenge}

Pip's relationship with Miss Havisham vis-à-vis Estella is one of denigration, deceit and revenge. His expectation to be betrothed to Estella is intentionally and maliciously ruined by the old lady. She brings Estella up to exact retribution on men by enticing them into falling in love with her, and then disappointing and deserting them (Chap. 22). She rears her to be an expansion of her own self in order to revenge love (Chap. 29). She wants Pip to grieve over the loss of love as she herself suffered from unrequited love in the past (Chap. 29). She urges Pip to fall in love with her. "I bred her and educated her, to be loved. I developed her into what she is, that she might be loved. Love her!" (Chap. 29, p. 425). When Estella is abroad "educating for a lady", Miss Havisham takes pleasure in informing Pip that she is now "far out of reach; prettier than ever; admired by all who see her" (Chap. 15, p. 205) Then, with "a malignant enjoyment" in her voice asks Pip if he feels he has lost her (Chap. 15, p. 205). To further spite Pip, Miss Havisham asks Estella to tell her all the names and particulars of the men whose hearts she has broken (Chap. 38).

Pip ultimately discovers there was no great plan by Miss Havisham to turn into a gentleman so that he can be an appropriate suitor for Estella. He is evidently dismayed to find out that Magwitch, not Miss Havisham, was his real benefactor. Such a revelation dashes his great expectation of being married to Estella (Chap. 39). When he protests over the manner in which Miss Havisham hinted that he and Estella were meant to be together, she coldly responds that it was his own mistake to believe that was the case (Chap. 44).

Miss Havisham also puts the prospect of Pip's relationship with Estella in jeopardy when she dismisses Pip from the Satis House, telling him that he is now Joe's apprentice and that he need not return to her anymore. Everyone celebrates the apprenticeship, which would keep Pip away from Estella, except for him. He feels deeply downhearted no matter how the adults stimulated him to be joyful. "I was truly wretched," says Pip, "and had a strong conviction on me that I should never like Joe's trade" (Chap. 13, p. 187). For he was anguished by the commonness of training to be a blacksmith (Chap. 14). She finally wreaked the revenge she had long yearned for: beholding a man as brokenhearted for Estella as she had been for the lover who jilted her (Chap. 44).

\section{Estella: Abuse, Incapability of Love, Drummle}

It is evident that Estella has been raised a string-puppet who will only act as manipulated by Miss Havisham to torment men in general and Pip in particular (Chap. 38). From the very first encounter, it is symbolically significant that Estella will work according to plan as she leads Pip 
into an obscure house and leaves him facing a shut door (Chap. 8). In Chapter 11, she again orders him to wait in a gloomy room (Chap. 11), a foreshadowing of his bleak future relationship with her.

\section{Abuse}

Even though Pip endeavors to behave in a well-mannered way, Estella always protests that he is rough and vulgar (Chap. 8). He describes her as "proud" and "insulting," "looking at me [...] with a look of supreme aversion" (Chap. 8, p. 106). She complains that he is a "common labouringboy," casting slurs on his appearance and conduct (Chap. 8, p. 104). The insults will affect Pip for a long period of time to come. "I fancied, as I looked at her," says Pip after many years, "that I slipped hopelessly back into the coarse and common boy again," and she, in response, treated him accordingly (Chap. 29, p. 416). Hurt, stunned and disgraced by the "very insulting" Estella, Pip could not keep himself from shedding bitter tears (Chap. 8, p. 106). Estella finds out and yet she asks for more: "Why don't you cry?" because "You have been crying till you are half blind, and you are near crying again now" (Chap. 8, p. 113). She does not conceal her sadistic pleasure with his pain (Chap. 8). He walks home downhearted and disappointed (Chap. 8). Thereafter, he continues to be ill-treated and offended by her (Chap. 12). She asks him if he still thinks she is abusive. He says that she seems less insulting for which she slaps and rebukes him. He falsely vows he would never cry for her anymore (Chap. 11).

Back home, Pip soon develops an aversion to the places and actions in which he used to rejoice before meeting Estella as she would not tolerate them (Chap. 14). He thinks of how common Estella would find his family and entourage if she were to see them (Chap. 9). He even thinks of running away to become a soldier or sailor and escape the common life he now detests (Chap. 14). But he will lose the company of his best "common" friends Joe and Biddy for the sake of an illusionary high-class love. Yet, Estella turns out to be the daughter of a convict father, Magwitch, (Chapter 50) and a mother who has a criminal record of choking a woman to death (Chap. 48). Over and above that, she will turn out to be incapable of love itself.

\section{Incapability of Love}

Estella has been effectively raised to be emotionless. "I have no heart," she tells Pip (Chap. 29, p. 421). Miss Havisham shattered her instinctive capacity to love (Chap. 49). She straightforwardly states that she is unable to love him or any other man. She is inept at the love of even her adoptive mother (Chap. 38). In fact, she is unconcerned about her own emotional life (Chap. 38). Pip is surprised that she speaks of herself "as if [she] were some one else" (Chap. 32, p. 472). She does not seem to show any personal excitement to see Pip, simply abiding by Miss Havisham's directions (Chap. 32). She is even astounded by Pip's show of emotion and does not appear to understand what love means (Chap. 44). He does not get any pleasure from her company as their encounters are very far from being romantic (Chap. 38). Being incapable of love, the most Estella could do for Pip is to warn him against falling in love with her (Chap. 44). She frankly tells Pip that she is unable to love even Drummle to whom she will soon be married (Chap. 44). Pip cautions Estella about Drummle's worthlessness but she looks unmoved and unworried. "[A]ll sorts of ugly creatures," says Estella, "hover about a lighted candle. Can the candle help it?" (Chap. 18, p. 553). 


\section{Drummle}

Pip cannot believe Estella can abandon him to flirt with Drummle. When the latter tells Pip that he has become Estella's lover, Pip dismisses his claim and nearly fights with him (Chap. 38). Drummle starts visiting Estella at the Satis House and their relationship gets closer (Chap. 43). Pip becomes disheartened to learn that Drummle has indeed begun courting Estella, frustrating him and her other admirers (Chap. 38). He entreats her, if she does not love him, to, at least, marry someone other than Drummle, and he would endure it for her sake (Chap. 44). Estella is confused by Pip's appeal and insists she will marry Drummle. Pip cries that he will never be able to forget her (Chap. 44).

As a result, All of Pip's desires and ambitions seem to be thwarted (Chap. 39). He designates himself as the "restlessly aspiring discontented me" (Chap. 14, p. 190). He laments the loss of everything. He abandoned Joe and Biddy for Estella's sake, but he never got close to her (Chap. 39). He regrets having treated them badly but in vain (Chap. 39). Finally, with Estella's insistence on marrying Drummle, Pip walks back to London extremely disappointed and retreats into loneliness (Chap. 44). He spends several weeks lovelorn, heartbroken and restless (Chap. 47).

\section{Biddy: Misunderstanding}

Biddy's personality stands in sharp contrast with Pip's. She frankly expresses her views of him and he wavers between acceptance and denial. His love also vacillates between her and Estella. Unlike Pip, Biddy is comfortable with her situation in life and does not endeavor to blindly try to climb the social ladder (Chap. 17). She maintains that human relationships should always have precedence over any other personal ambitions (Chap. 17). Her own desire to become a teacher does not cause her to abandon her past acquaintances (Chap. 35). Furthermore, she does not look at Estella through Pip's rose-colored glasses; she can see her harshness and triviality for what they are (Chap. 17).

She actually loves Pip but he loves Estella who has been trained not to love (Chap. 35). She sensibly puts it to Pip that it is illogical for him to seek to become a gentleman in order to gain over a woman who is "not worth gaining over", a woman who thinks him unmannered and common (Chap. 17, p. 229). Pip knows it unconsciously; he bursts into tears, but cannot stop loving Estella (Chap. 17). Biddy expresses her doubt about Pip's expectations and calls them "a pity" (Chap. 17, p. 227). She is upset by Estella's rude offenses and asks Pip to disregard her, not "to gain her over" (Chap. 17, p. 228). She is insightful and brutally honest, even if it does not please Pip. It is not difficult for her to discern that Pip's class aspirations will lead him to desert his acquaintances (Chap. 17). She clearly notices that Pip's material transformation has changed him into a pretender and a fool. He immediately starts describing his co-villagers with the same words Estella used to insult him, "coarse" and "common" (Chap. 18, p. 257). Biddy knows his real personality and feelings and is shocked at his pretentiousness. (Chap. 18)

Pip tells Biddy that he wishes he were happy in his present situation and he wishes he could love her. "But you never will, you see," she says (Chap. 17, p. 232). He often gets her wrong. He gets the wrong impression about the sorrow in her congratulations of him on his new fortune, not realizing that she is sad because she loves him, not because she envies him (Chap. 18). Pip condemns Biddy's "bad side of human nature" (Chap. 35, p. 503). He tells her he is offended by 
her distrust of him (Chap. 35). In fact, Pip's heart keeps wavering between Biddy and Estella. He feels jealous and shows a strong desire to shield Biddy against Orlick who wants to court her. However, he himself is uncertain about his feelings towards her (Chap. 17). He appears to be torn between believing in Biddy and forge life on the one hand and Estella and high-class life on the other (Chap. 17). While walking with Biddy, he thinks how wretched he would be if he were walking beside Estella (Chap. 17). Despite the fact that a part of Pip's mind approves of Biddy's views, he is overcome by his displeasure with life at the forge and fixation with Estella (Chap. 17). By the time he realizes his mistakes and decides to go back to his village and propose to Biddy towards the end of the novel, it was too late: He coincidentally arrives there on her very wedding day (Chap. 58). Biddy tries to persuade Pip to get married, he immediately recalls Estella even though he says he no longer yearns for her (Chap. 59). In despair, Pip tells Biddy that he thinks he will never get married (Chap. 59).

\section{Pip's Other Friends: Contrast}

The fact that Pip's friends have achieved happiness in love while he accomplished nothing compounds his frustration (Chap. 55). Just like the way young Pip began, Herbert is a man with limited resources but large dreams. Yet, unlike Pip, he is assiduous and honest. And unlike Pip's relationship with Biddy and Estella, Herbert's genuine love of a woman who is poorer than himself, and who does not meet his mother's high standards and obsession with inherited titles, reveals his decent and upright character. Pip notices that good things have come to Herbert, not to himself (Chap. 55). Similarly, Wemmick's kindness to those around him has earned him a decent life with a good wife (Chap. 55). Besides, Herbert's description of Estella confirms the news that Miss Havisham indeed brought her up to wreak revenge on the male gender (Chap. 22). That is why Herbert directs Pip to disassociate himself from Estella because her upbringing "may lead to miserable things" (Chap. 30, p. 444).

\section{Pip: Distress}

Pip's love for Estella is mostly a source of misery, frustration, horror, captivity and jealousy. He concedes that he "never was happy with her, but always miserable" (Chap. 33, p. 481). He describes his love relationship with her asserting that "I suffered every kind and degree of torture that Estella could cause me" (Chap. 38, p.535). He bitterly admits that he "never had one hour's happiness in her society" (Chap. 38, 536). Out of frustration, Pip declares to Biddy that he thinks he will never get married. To Herbert, he admits that he desires Estella deeply but does not seem to be able in the least to get her to budge (Chap. 30). His love for Estella has even forced him into turning proud and snobbish (Chap. 33) for he is horrified at the possibility of Estella seeing him in his scruffy blacksmith state (Chap. 14). Besides, like Estella, Pip feels stuck in Miss Havisham's scheme. "We have no choice, you and I," says Estella, "but to obey our instructions. We are not free to follow our own devices, you and I' (Chap. 33, p. 470). Both think themselves ensnared even though both can escape their current situation if they have the will to do so. They could close their eyes to Miss Havisham's instructions and change their plans, but they would not. Furthermore, Pip is wretchedly distraught that Estella started courting Drummle, the most repugnant of his associates (Chap. 38). This is demonstrated through the conversation in which Jaggers praises "Spider" Drummle and troubles Pip (Chap. 48, p. 693). And even though Pip and Drummle exchange vulgar words and part ways (Chap. 43), that does not prevent Drummle from actually 
marrying Estella (Chap. 48). Pip is also aware of his self-deception when he acts unfaithfully and dishonestly towards Joe and Biddy for the sake of Estella (Chap. 28).

Pip's disillusionment with love, revealed through his distress at the attitudes of Estella, Miss Havisham, Biddy, Pip and his friends, brings Pip to his knees. His ego cannot be in a worse situation. But how does he ultimately succeed in finding a way for his id through all of those superego cruelties?

\section{Part Four: Healthy Ego}

The journey of Pip's ego towards achieving his dream of winning Estella's heart finally becomes conceivable. A number of important factors contribute to the success, including Miss Havisham's repentance, Estella's painful experience from which she realizes Pip's worth, and Pip's own transformation into a mature gentleman.

\section{Miss Havisham: Regret and Repentance}

Just as Miss Havisham has contributes to Pip's ailing ego, she also helps him heal. Even her deception seemed to positively impact his personality. She made him live the sweet dream of being meant to be betrothed to Estella. She often draws his attention to Estella's beauty (Chap. 11), ordering him to "love her, love her, love her" (Chap. 29, p. 425). She arranges for them to spend time together and asks him to escort her to Satis House back from London (Chap. 38). It was all part of her plan to destroy Pip but he happily swallows the bait and infers that Miss Havisham is a benefactress who is going to make his dreams come true by preparing him to become an appropriate suitor for Estella (Chap. 18). Her order for him to "love her" keeps resonating in his mind and he feels indebted to her for her supposed generosity (Chap. 29). Infatuated with Estella, he misguidedly presumes that Miss Havisham has covertly engaged Estella to him and that she wants her to wreak revenge on any other men except himself (Chap. 38).

When Pip discovers the truth, his pain is alleviated by Miss Havisham and Estella's dispute and the breakup of their evil alliance against him (Chap. 38). Estella attempts to twist free from Miss Havisham's tightened grip. Incensed, Miss Havisham reproaches her for ungratefulness and cruelty. "I am what you have made me," replies Estella, "Take all the praise, take all the blame; take all the success, take all the failure" (Chap. 38, p. 541). Miss Havisham wails that Estella would consider even love for her to be "weakness" (Chap. 38, p. 544).

Miss Havisham's repentance also relieves Pip's distress as she finally identifies and commiserates with Pip when he breaks down in front of her, remembering how her own heart was broken and life ruined (Chap. 44). She shows affectionate distress for his misery (Chap. 49). She watches his eruption with a "ghastly stare of pity and remorse" (Chap. 44, p. 647). She kneels at his feet. "'O!' she cried, despairingly, 'What have I done! What have I done'" (Chap. 49, p. 709). She recognizes and regrets having raised Estella wrongly as a puppet without a human heart (Chap. 49). Her revengeful side ultimately vanishes and she asks Pip to pardon her, which he immediately grants knowing that he needs forgiveness himself (Chap. 49). Furthermore, when he finds her on fire, he takes the risk and burns himself badly in order to save her (Chap. 49). Pip's willingness to

Arab World English Journal for Translation \& Literary Studies 
forgive Miss Havisham shows his unrequited love experience has made him a better person, more empathetic and less resentful (Chap. 49).

\section{Biddy: Love and Tolerance}

Pip first delights in his feeling of superiority to Biddy. Jaggers' news about Pip's fortune satisfies the pride he acquired working for Miss Havisham and the superiority he feels towards Joe and Biddy (Chap. 18). He even blames Biddy for being dishonest when he should be blaming himself for the same reason (Chap. 35). Yet, Biddy's kindness forces him to mature and fall in love with her. She often consoles him and expresses her happiness with his confidence in her. He hugs her and promises to always tell her everything (Chap. 17). Even when it comes to her rival Estella, Biddy sends Joe to tell Pip that Estella is home and would like to see him (Chap. 27). Biddy goes as far as offering Pip her apologies even though she was not wrong (Chap. 35) (4)

Trying to put things right, Pip decides to propose to Biddy (Chap. 57). He dreams of the unpretentious happy life he would lead with her (Chap. 58). He wants his future to be guided by her goodness and decides to work at any job she recommends (Chap. 57). He has morally matured being finally conscious of his faults and able to appreciate the genuine internal rather than pretentious apparent value of people (Chap. 57). When he decides to marry her but discovers it is very late, he does not act with anger, disappointment or bitterness in response to Joe and Biddy's marriage, but rather with heartfelt delight in their happiness (Chap. 58). Furthermore, he starts to feel part of Joe and Biddy's sympathetic family, with no more dreams of leaving their ordinariness behind as he once did (Chap. 59).

\section{Estella: Transformation}

Even though Estella is the main contributor to Pip's distress throughout the novel, she occasionally helps lift his spirits and ultimately becomes a potential source of his happiness in the future. Right from the beginning of their interaction, Estella tells Pip "You may kiss me, if you like" (Chap. 11, p. p. 162). She lets him kiss her because his win in the fight raises her opinion of him. Then they sometimes sing together (Chap. 12). Pip also takes pleasure in the news about Estella's visits to London where he can meet her at the carriage stop (Chap. 32). He hopes Estella is content with their relationship and hints at the fact that she would act more affectionately towards him were it not for Miss Havisham's rigorous instructions (Chap. 32). Likewise, Pip feels satisfied when Estella tells him that Miss Havisham's relatives begrudge him and are unsuccessfully plotting against him, trying to smear Miss Havisham's opinion of him; she expresses her delight in their failure (Chap. 32). Again, when Pip declares to Estella that he resents the attention she gives Drummle, Estella tells him that she is deceiving and entrapping Drummle and all her other suitors except Pip (Chap. 38). With Pip, she is being straightforward about her nature and incapability of love (Chap. 38). She tells him that she has never misled or tricked him even though she has falsely flirted with many men and broken their hearts (Chap. 38).

Then, to Pip's amazement, comes Estella's unbelievable transformation from an emotionless to a sensitive lady. Her husband treats her coarsely and because of her disappointment, she seems to have learnt the meaning of happiness, which prepares her and Pip for a hale and hearty relationship (Chap. 59). She says pain has transformed her (Chap. 59). She has attained kindness and honesty through suffering (Chap. 59). She tells Pip that she has experienced a severe 
heartbreak and now asks him for forgiveness. She tells Pip she has been thinking about him and regrets having discarded his love (Chap. 59). She has actually been a casualty of Miss Havisham's hostile attitude towards men. It is astounding that she ended up stable or with any emotions at all (Chap. 59). At the end, it is uncertain whether Pip and Estella will get married or just stay friends (Chap. 59). But Pip "saw no shadow of another parting from her" (Chap. 59, p. 865). All in all, she can be considered a valuable reward for the upright gentleman Pip becomes at the end (Chap. 59). Pip's ego fluctuations between his id and superego ultimately permit him to see the light at the end of the tunnel. Miss Havisham and Estella experience a positive change that make a love relationship between Pip and Estella conceivable in the future.

\section{Conclusion}

The use of the three Freudian subdivisions of the mind to examine the fluctuations of Pip's ego between the id and superego in Charles Dickens's Great Expectations has proven to be operative. For the study has managed to answer its key research questions, reaching the following results: First, Pip's id, his strong desire to win Estella's love, is illustrated in his feelings and actions alike. Second, Pip's superego is mainly constructed from the characters that stand in the way of his quest for love. Third, Pip's disillusionment with love, revealed through his distress at the attitudes of Estella, Miss Havisham, Biddy and his friends, bring Pip's ego to its knees. Fourth, the quest of Pip's ego for winning Estella's heart finally becomes possible thanks to such factors as Miss Havisham's repentance, Estella's painful experience from which she realizes Pip's worth, and Pip's own transformation into a mature gentleman.

As in the case of Saoudi et al. (2021), applying Freudian criticism to the analysis of the theme of love in Great Expectations has proven to be a productive exploration of literature. This project can be taken as a model to study other works of literature that lend themselves to examination through psychoanalytic criticism, or even other aspects of Dickens's same novel.

\section{About the Authors:}

Bechir Saoudi got his Ph.D. in English Literature and Cultural Studies from the University of Manouba, Tunisia. He is currently an Assistant Professor of English literature at the English Department of the College of Science and Humanities, Hotat Bani Tamim, Prince Sattam bin Abdulaziz University, Al-Kharj, Saudi Arabia. His research interests are in the literary and cultural studies domain. ORCiD: https://orcid.org/0000-0001-5593-6891

The rest of the authors are graduate students of English Language and Literature at the College of Science and Humanities, Hotat Bani Tamim, Prince Sattam bin Abdulaziz University, Al-Kharj, Saudi Arabia.

\section{Ameerah Ali Al-Bedewy}

ORCiD: https://orcid.org/0000-0001-6334-1361

Fatima Ali Al-Anzan

ORCiD: https://orcid.org/0000-0001-7297-6895

Lulwah Mohammad Al-Sebr

ORCiD: https://orcid.org/0000-0002-9175-9113

Nouf Mohammad Al-Smari 
ORCiD: https://orcid.org/0000-0002-5321-6660

Nora Ali Al-Tamimi

ORCiD: https://orcid.org/0000-0002-5836-8559

\section{References}

Bloom, H. (Ed.). (2010). Bloom's Modern Critical Interpretations: Great Expectations. Chelsea House Publications.

Brooks, P. (1980). "Repetition, Repression, and Return: Great Expectations and the Study of Plot", New Literary History, 11 (3): 503-526, doi:10.2307/468941

Dessner, L. J. (1976). Great Expectations: "The Ghost of a Man's Own Father". PMLA, 91(3), 436-449.

Dickens, Charles. (1861). Great Expectations. London: Chapman and Hall. https://etc.usf.edu/lit2go/140/great-expectations/

Freud, S. (1927). The Ego and the Id (J. Riviere, Trans.). Hogarth Press. (Original work published 1923)

Freud, S., Strachey, J., \& Richards, A. (1984). On Metapsychology: The Theory of Psychoanalysis : 'Beyond the Pleasure Principle, ' 'The Ego and the Id' and Other Works. Harmondsworth: Penguin.

Great Expectations. (2020). In Encyclopadia Britannica Online. Retrieved from https://www.britannica.com/topic/Great-Expectations-novel-by-Dickens

Hrubes, M. (2003). Great Expectations: The strange romance of Pip and Estella.

Grin.com. https://www.grin.com/document/36426

Ingham, G. (2007). The Superego, Narcissism and Great Expectations. The International Journal of Psychoanalysis, 88(3), 753-768.

Lehman, D. (2004). Repressions in 'Great Expectations'. Retrieved from https://danielmlehman.wordpress.com/2004/04/20/repressions-in-great-expectations/

Reynolds, C. W. (2015). Desiring Estella in Great Expectations: Understanding Pip's

Fantasy. Retrieved from

http://www.victorianweb.org/authors/dickens/ge/reynolds.html

Saoudi, B., Al-Eid, L. F., Al-Break, N. M., Al-Samih, R. S., Al-Hammad, T. A. (2021). Bechir Saoudi. Arab World English Journal for Translation \& Literary Studies 5

(1) 262 -278. DOI: http://dx.doi.org/10.24093/awejtls/vol5no1.19

Schlicke, P. (1999). Oxford Reader's Companion to Dickens. Oxford: OUP.

Snyder, C. R., \& Lopez, S. J. (2007). Positive Psychology. Sage Publications Inc.

Tyler, D. (2011). "Feeling for the Future: The Crisis of Anticipation in Great

Expectations", 19: Interdisciplinary Studies in the Long Nineteenth

Century 0(14). Retrieved from https://doi.org/10.16995/ntn.60.

Arab World English Journal for Translation \& Literary Studies 